Annals of Warsaw University of Life Sciences - SGGW

Land Reclamation No 41 (2), 2009: 109-118

(Ann. Warsaw Univ. of Life Sciences - SGGW, Land Reclam. 41 (2), 2009)

\title{
Quality changes of drinking water in the water supply network (case study from Lithuania)
}

\author{
MARINA VALENTUKEVICIENE, AUKSE AMOSENKIENE, \\ REGIMANTAS DAUKNYS \\ Department of Water Management, Vilnius Gediminas Technical University, Lithuania
}

\begin{abstract}
Quality changes of drinking water in the water supply network (case study from Lithuania). The purpose of this research was to examine water quality changes by distributing in to the water supply network. Water samples were collected from Varena town (Lithuania) drinking water distribution system fed by groundwater from well field. Parameters related to undesirable increasing of nitrites and nitrates concentrations have been measured considering these samples: $\mathrm{pH}$, conductivity, concentration of total iron, manganese, ammonium, nitrates and nitrites. Results showed that groundwater from well field were extremely susceptible to favor bacterial growth in the pipelines. The occurrence of nitrites and nitrates in drinking water samples correlated positively with the lengths of old iron pipelines and negatively with the content of newly laid pipelines. The obtained results also showed that the potential nitrates increasing induced by the distribution of treated water could be reduced if: nitrates levels were below detection limits at the outlet of the water treatment plant; biological ammonium removal treatment implementation should reduce the levels of the nitrates and nitrites of the treated supplied water. Although the nitrates concentration increase in drinking water distribution systems, the issues with nitrites accumulation are rare in Lithuania. However, such processes still need to be proved in more extensive investigation, but these research results could be applied as a basic scenario.
\end{abstract}

Key words: drinking water, nitrites, nitrates, water treatment, water supply.

\section{INTRODUCTION}

In Lithuania drinking water is supplied from groundwater sources. It is safe and corresponds Lithuanian Hygienic Norm
HN 24:2003 "Requirements for Safety and Quality of Drinking Water". In the case of any separate user the quality of water can be influenced by the state of the water supply network, the intensity of water consumption, water temperature (Agatemor and Okolo 2007).

The quality of drinking water is evaluated according to microbial parameters, toxic (chemical) and indicatory parameters. In EU directive 98/83/EC "On the quality of water intended for human consumption" microbial parameters are defined for determination of permissible limits. There can not be found Coliform bacteria, Escherichia coli, Enterococcusfaecalis in drinking water for human consumption. The total quantity of colonies can be estimated at the temperature of $22^{\circ} \mathrm{C}$. However, drinking water should be acceptable for consumers and without non-characteristic changes.

In pipelines bacteria form coloniesknobs from products of corrosion. In colonies-knobs bacteria maintain reducing environment for further corrosion, even if the environment in pipeline is not reducing enough or even if it is oxidizing. Sulphates and chlorides are accumulated at the knobs. In this way the favourable conditions are created for sulphate and nitrite reducing 
micro organisms and nitrite, ammonium and sulphur oxidizing micro organisms. According to the research the micro organisms that live in raw water sources have also favourable conditions to survive in pipelines (Mari et al. 2002).

In water existing ammonium and nitrate create favourable conditions for anaerobic ammonium oxidizing bacteria $(\mathrm{AOB})$ and nitrate reducing bacteria.

Ammonium oxidizing bacteria turn ammonium into nitrite and then nitrite oxidizing bacteria (NOB) turn nitrite into nitrate. When in water the quantity of AOB increases, the quantity of nitrite increases as well. Therefore, the total growth of micro organisms can increase as well (Lehtola et al. 2004).

Microbiological nitrification process can cause interference of chemical, microbiological and technical characters at networks of water supply (Lee et al. 2005).

Scientists of Water Management Department of VGTU experimentally determined that it is possible to use natural sorbent zeolite (clinoptilolite) for the removal of nitrogen compounds. The efficiency of removal reached up to $99.9 \%$, though more researches should be carried out at this field (Mazeikiene et al. 2008; Valentukeviciene and Rimeika 2007). Changes of nitrogen compounds are caused by bacteria in the pipeline of water supply. Various water micro organisms at underground water get into pipeline of water supply. Micro organisms get into drinking water from the surrounding environment as well. Depending on the admixtures in water, quantity of dissolved oxygen, material of pipeline and other factors the conditions favourable for the vital activity of micro organisms can be created in pipeline of water supply. Scientists noticed that there form sediments in pipelines because of the activity of micro organisms, the water has unpleasant taste and smell, the corrosion of pipes starts (Neville 2001). Ammonium is usually found in Lithuanian groundwater (Mazeikiene et al. 2008; Valentukeviciene and Rimeika 2007; Valentukeviciene 2009). Groundwater is aerated during its treatment for drinking purposes. Then the quantity of dissolved oxygen increases. In this way favourable conditions for AOB activity are created. The AOB participate in the nitrification process that has two stages.

A number of nitrifying bacteria genera participate at both stages. Nitrite, that are the products of stage one, are initial material for stage two. As it turned out, there doesn't exist bacteria that were able to carry out both stages, so both bacteria groups participate in the process of nitrification (nitrozo bacteria and nitro bacteria) (Mari et al. 2002). During both stages of nitrification the energy is created that nitrificators consume for the assimilation of $\mathrm{CO}_{2}$. Thus nitrifying bacteria are autotrophs in respect of carbon: complex compounds are not necessary for their vital activity. As energy (in a form of adenosintriphosphate (ATP)) yield is low, the bacteria have to process big quantities of nitrogen compounds in order to get the sufficient quantity of ATP. The bacteria, that participate at stage one, have to oxidize approximately 35 molecules of ammonium to fixate one molecule of $\mathrm{CO}_{2}$ and the bacteria of stage two have to oxidize approximately 100 molecules of nitrite. Processing 
big quantities of nitrogen compounds nitrifying bacteria grow much slower than other kinds of bacteria even if nitrification process is intensive (Mari et al. 2002). Chlorinating water nitrite can be formed at least in couple ways. The AOB oxidize chloramines $\left(\mathrm{NH}_{2} \mathrm{Cl}\right)$ into nitrite (Srinivasan et al. 2008). Though it is possible an opposite variant, as speeded up destruction of chloramines at nitrite environment, that is why the concentration of nitrite in water can decrease. Ammonia is formed, which in water is hydrolysed into ammonium.

It is also possible the process of denitrification that is opposite to the nitrification process. Denitrification is multi-stage process which usually finishes by formation of gas nitrogen. But when $\mathrm{pH}$ is lower or equal to $7, \mathrm{~N}_{2} \mathrm{O}$ can be formed. Denitrification is one of the variants of anaerobic respiration (nitrate respiration), when $\mathrm{NO}_{3}^{-}$ions as the final acceptor of electrons are used for oxidizing of organic substances. Heterotropic bacteria such as Pseudomonas, Spirillium, Tiobacillus, Bacillus, Alcaligenes and bacteria of some other genera carry out the process (Lee et al. 2005).

In pipeline the ammonification process could occur as well. This is the decomposition of nitrogen compounds into non-organic forms $\left(\mathrm{NH}_{3}\right)$. A lot of bacteria and fungi participate in this process. The most active ammonificators are bacteria of Pseudomonas and Bacillus genera as well as Proteus vulgaris and Escherichia coli. When chlorinated water flows through the water supply network (there are chloramines in water), chloramines react with biomaterial (its typical chemical composition is
$\left.\mathrm{C}_{5} \mathrm{H}_{7} \mathrm{O}_{2} \mathrm{~N}\right)$ that is created by micro organisms during the disinfection (Mari et al.2002). Rather big additional quantity of ammonium occurs in water as a result of the abovementioned reaction.

\section{MATERIALS AND METHODS}

Field research was carried out in water supply network of Varena town (Lithuania). Varena is the town in the south of Lithuania in Alytus region, 51 kilometres in the south-east of Alytus. Varena district consist of the town of Varena with 10800 inhabitants, 7 settlements (2937 inhabitants) and 42 smaller villages (1383 inhabitants).

The main task of JSC "Varenos Vandenys" is water supply, wastewater collection and treatment in the town of Varena and the main settlements of Varena district. At present the company services 25 watering-places with 39 exploited artesian wells and 9 water-towers.

In order to evaluate changes of water quality a network of water supply in Varena town was selected as well as the networks of water supply in the settlements of Panara and Zilenai. In order to evaluate the quality of drinking water that is supplied through the networks of pipes in Varena town and the settlements of Panara and Zilenai properly, over 100 water samples were analysed. The analyses of samples were carried out at the laboratory of JSC "Vilniaus Vandenys" which is certified for carrying out microbiological, physical and chemical analyses of drinking water. Approximately 33 analyses were carried out for each sample. 
The town of Varena hasn't got any water treatment plant. Water is pumped from the artesian wells with the depth of 80 meters and supplied through pipes made of steal and cast iron to the water tower and then to the consumers. In Varena town watercourses and branched pipelines are old. They made of steal and cast iron. Only in a new district of Varena the pipework of ductile cast iron is installed.

A water quality analysis was made and certain technological paremeters were determined for the control and evaluation of water quality changes processes using international standard methods: total iron concentration, $\mu \mathrm{g} / \mathrm{L}$; manganese concentration, $\mu \mathrm{g} / \mathrm{L}$; ammonium ions concentration, $\mathrm{mg} / \mathrm{L}$; nitrates and nitrites concentrations, $\mathrm{mg} / \mathrm{L}$; conductivity $\mu \mathrm{Scm}^{-1}$ (when water temperature $25^{\circ} \mathrm{C}$ ) and other relevant parameters (e.g. pH, turbidity). The quantitative results are presented as the arithmetic mean of six independent measurements $(\mathrm{x} \pm \mathrm{SD}, \mathrm{n}=6)$. Significant differences $(p<0.05)$ were removed from the results estimations and the measurements were analysed once again.

The data from the experimental investigation was statistically calculated from the registered analyses. The concentration of substances (Fe, Mn and $\mathrm{NH}_{4}{ }^{+}$) was measured 11 times in raw water, in taps of users and in the water storages reservoires. The average concentration at typical points was:

$$
\bar{c}=\frac{1}{n} \sum_{i=1}^{k} c_{i} m_{i}
$$

Where: $c_{i}$ - concentration of substances at typical points, $m_{i}$ - probability at the occurrence of concentration; $n$ - number of days; $k$ - number of different values of the concentration.

The average concentrations of substances, mentioned above, at the characteristical point were also calculated. The standard statistical estimation error of the arithmetic average was approximatly $11 \%$.

\section{RESULTS AND DISCUSSIONS}

The values of the quality of water samples that were taken at the characteristic points of the pipeline of water supply network of Varena town are presented in Table 1 and Figures 1 and 2.

The diagram in Figure 1 and results in Table 1 show that in water fields, that are located in distances $(L)$ of 250 $\mathrm{m}, 300 \mathrm{~m}, 300 \mathrm{~m}$ and $400 \mathrm{~m}$ from the water-tower, the values of nitrate are less than at the water-tower. Data from the research showed a dependency between nitrate, nitrite and pipeline length at the characteristic points of network of water supply and was established a third order polynomial regression type:

$C_{\mathrm{NO}_{3}}=-0.5292 L^{3}+4.6668 L^{2}+$

$+12.9644 L+17.528$

$\left(R^{2}=0.72\right)$

$C_{\mathrm{NO}_{2}}=-0.014 L^{3}+0.1185 L^{2}-0.2845 L+$ $+0.2126$

$\left(R^{2}=0.9969\right)$

The water flows from the water fields into the water tower through old pipelines made of cast iron. The quantity of nitrate in water at the water tower increases 


\begin{tabular}{|c|c|c|c|c|c|c|c|c|c|c|c|}
\hline 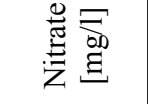 & $\begin{array}{c}0 \\
\infty \\
\infty \\
\dot{f}\end{array}$ & $\begin{array}{l}0 \\
\stackrel{0}{0} \\
\infty \\
\infty\end{array}$ & & & & ف. & \begin{tabular}{|l}
8 \\
0 \\
$i n$ \\
in
\end{tabular} & $\stackrel{8}{\stackrel{9}{0}}$ & $\begin{array}{l}8 \\
\vdots \\
0 \\
0\end{array}$ & $\begin{array}{l}8 \\
\infty \\
i \\
i j\end{array}$ & $\mid \begin{array}{l}\stackrel{R}{\infty} \\
\stackrel{\infty}{-}\end{array}$ \\
\hline 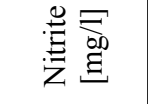 & $\mid \begin{array}{l}\mathbf{1} \\
\dot{8} \\
0\end{array}$ & $\stackrel{n}{\circ}$ & $\begin{array}{c}0 \\
\vdots \\
0 \\
0\end{array}$ & $\begin{array}{l}0 \\
0 \\
0\end{array}$ & $\begin{array}{c}m \\
\tilde{c} \\
\dot{0}\end{array}$ & 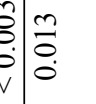 & $\mid \begin{array}{l}\hat{8} \\
\dot{8} \\
\dot{0} \\
v\end{array}$ & 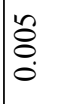 & $\begin{array}{l}0 \\
\dot{0} \\
0 \\
0\end{array}$ & ô & 苂 \\
\hline 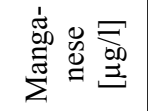 & $\simeq$ & $\stackrel{\infty}{\infty}$ & 이 & $=5$ & $7 \approx$ & $\hat{\imath} \mid \stackrel{0}{0}$ & $\infty$ & 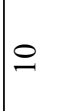 & $\infty$ & r & \pm \\
\hline 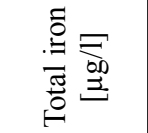 & $\underset{\sim}{\infty}$ & $\begin{array}{l}0 \\
v \\
v\end{array}$ & $\begin{array}{l}6 \\
V\end{array}$ & \begin{tabular}{l|l}
0 \\
$v$
\end{tabular} & $\begin{array}{l}b \\
\vee\end{array}$ & 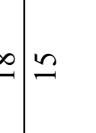 & $\approx$ & 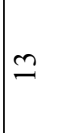 & $\stackrel{\infty}{-}$ & 6 & $a$ \\
\hline 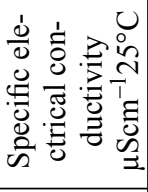 & 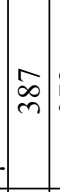 & $\underset{\mathrm{N}}{\mathrm{N}}$ & fol & & $\begin{array}{c}\Delta \\
m\end{array}$ & $\hat{n}=\hat{n}$ & $\vec{m}$ & $\hat{n}$ & సे & 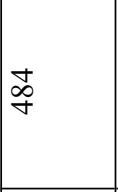 & สิ \\
\hline 贾 & $\mid \begin{array}{l}\infty \\
\infty \\
\sim\end{array}$ & $\begin{array}{l}\infty \\
\infty \\
\sim \\
\sim\end{array}$ & 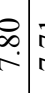 & $\begin{array}{ll}\therefore \\
\therefore\end{array}$ & 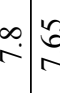 & : & $\vec{b}$ & $\stackrel{\infty}{\stackrel{\infty}{r}}$ & $\stackrel{n}{?}$ & 㒸 & $\stackrel{0}{\stackrel{0}{r}}$ \\
\hline 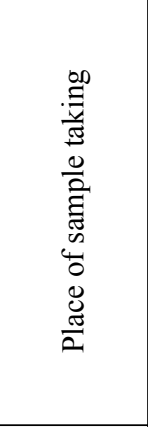 & 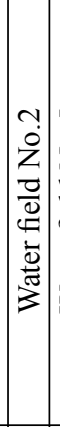 & 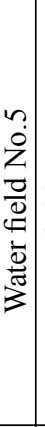 & 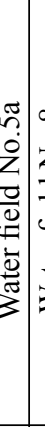 & 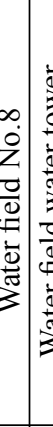 & 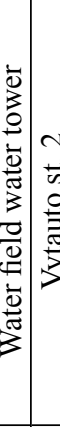 & 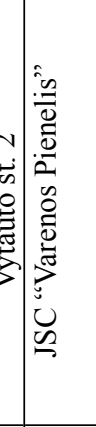 & 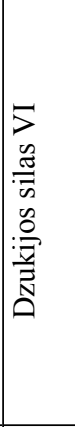 & 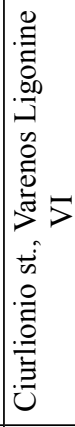 & 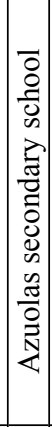 & 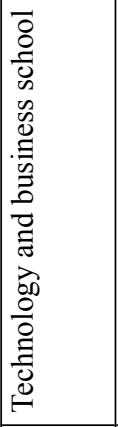 & 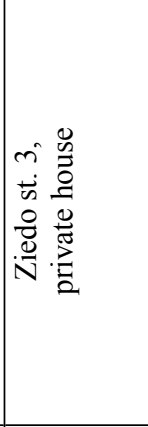 \\
\hline 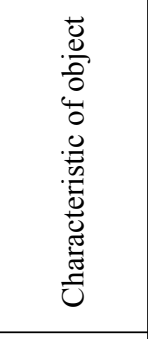 & 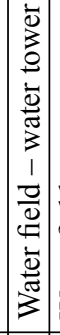 & 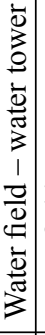 & 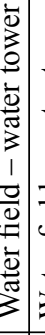 & 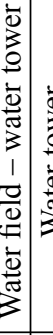 & 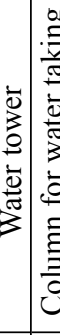 & 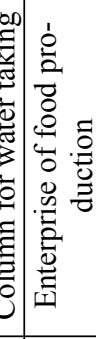 & 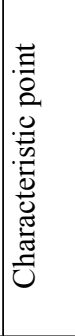 & 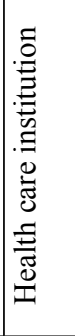 & 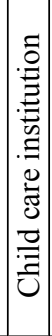 & 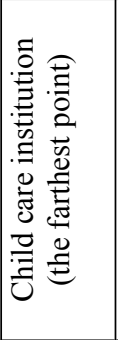 & 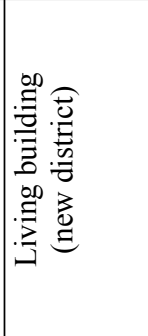 \\
\hline 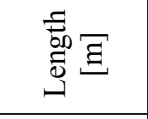 & $\stackrel{0}{2}$ & \&্ল & & 8 & $\begin{array}{l}8 \\
\text { in }\end{array}$ & : & পঃ & $\gtreqless$ & $\mid \begin{array}{l}8 \\
2 \\
2\end{array}$ & đે̀ & ¿ \\
\hline 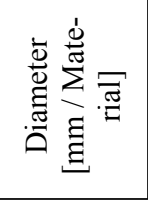 & 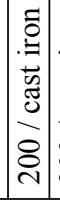 & & 용. & 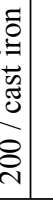 & $\begin{array}{ll}5 \\
.5 \\
5 \\
5 \\
5 \\
\text { in } \\
\end{array}$ & 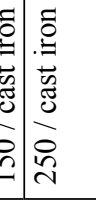 & 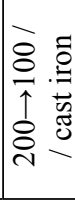 & 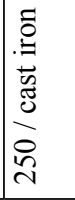 & 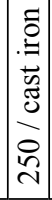 & 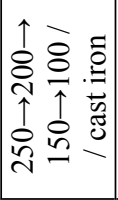 & 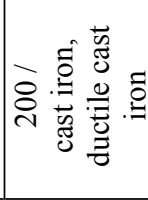 \\
\hline
\end{tabular}




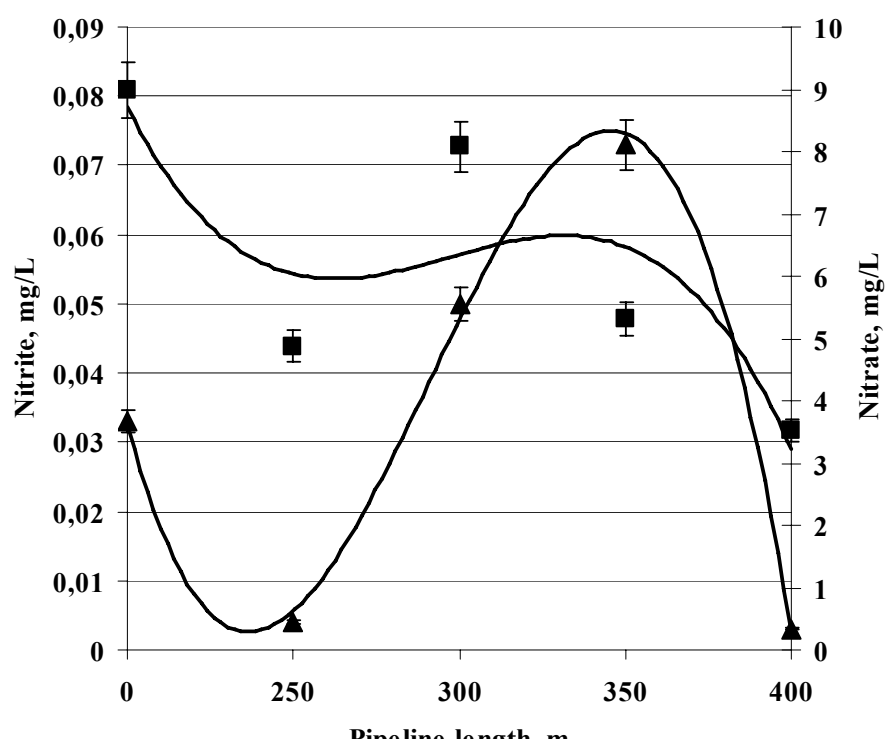

Pipeline length, $m$

$\Delta$ Nitrite $\mathbf{a}$ Nitrate $-\longrightarrow$

FIGURE 1. Dependency between nitrite, nitrate and pipeline length in water-tower of Varena town and at the water fields those are located in different distances from the water-tower

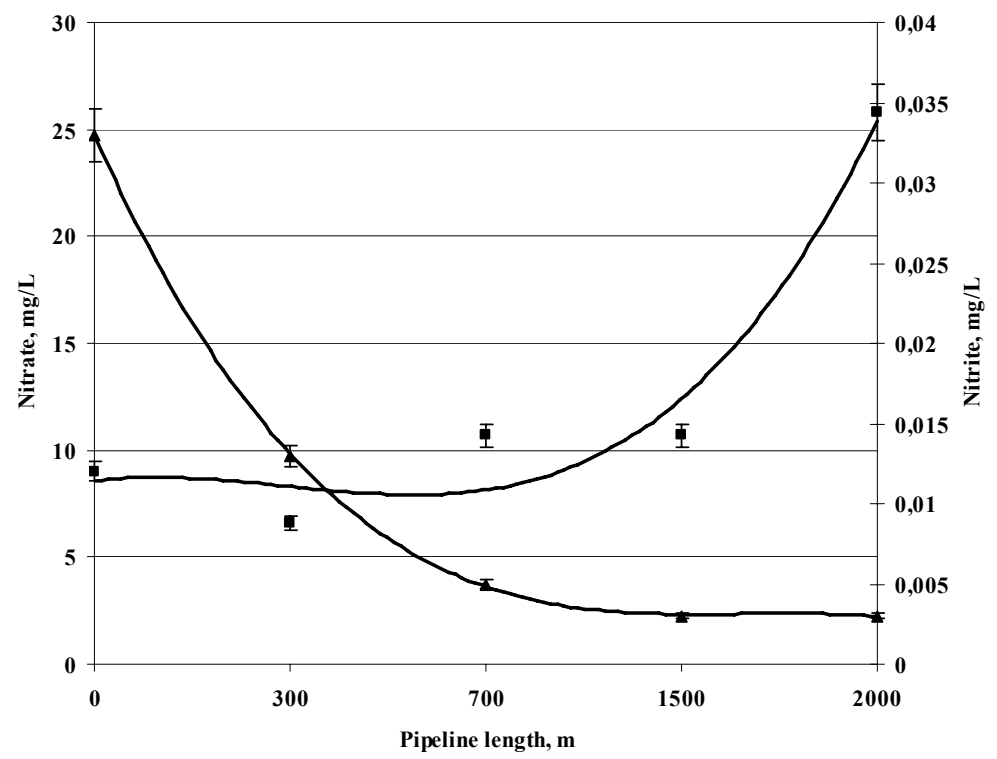

- Nitrate $\Delta$ Nitrite $\longrightarrow$

FIGURE 2. Dependency between nitrite, nitrate and pipeline length at the characteristic points of network of water supply of Varena town 
because of the nitrification process in the old pipelines.

The water at the water tower is a mixture of water from all wells located in different water fields, so the consistency of changes of nitrite and nitrate is not possible to determine.

According to the presented diagram in Figure 2 and the values in Table 1 the biggest quantity of nitrate (25.80 $\mathrm{mg} / \mathrm{L}$ ) was determined in the farthest characteristic point $(2000 \mathrm{~m})$ in respect of the water tower (Technology and business school). The result is caused by the old pipes of cast iron, which connect the water tower and a tap of consumer. As a result of the nitrification process in the pipelines nitrite are formed and later they turn into nitrate. Data from the research showed a dependency between nitrate, nitrite and pipeline length $(L)$ at the characteristic points of network of water supply and was established a third order polynomial regression type:

$C_{\mathrm{NO}_{3}}=0.7175 L^{3}-4.2518 L^{2}+7.4707 L+$ $+4.628$

$\left(R^{2}=0.945\right)$

$C_{\mathrm{NO}_{2}}=-0.0008 L^{3}+0.0108 L^{2}-0.0464 L+$ +0.0694 , $\left(R^{2}=0.9999\right)$.

Obtained results show that different quantities of nitrate are found in the pipelines of equal length but of different material they are made of. In the old pipeline of ductile cast iron (length is $2000 \mathrm{~m}) 1.870 \mathrm{mg} / \mathrm{L}$ of nitrate were determined and at the pipeline of cast iron (length is $2000 \mathrm{~m}$ ) $25.80 \mathrm{mg} / \mathrm{L}$ of nitrate were determined. In the new pipeline the quantity of nitrates decreased 4.8 times and in the old one it increased 2.8 times in comparison to the quantity of nitrates in water at the water tower.

The more distant from the water tower and closer to the consumer the more nitrite are oxidized into nitrate. The process starts because of the increasing of quantity of dissolved oxygen in water. The concentrations of ammonium at the selected characteristic points of Varena water supply pipeline are rather small and they can not be defined.

The settlement of Panara hasn't got any water treatment plant. The water is supplied using PE pipes. The settlement of Zilenai has got water treatment plant for iron removal, but after the treatment water is supplied using old pipes of cast iron.

The results of the quality of samples from Panara and Zilenai water fields, as well as from the characteristic points are presented in Table 2. Almost all wells at Panara and Zilenai settlements are not deep, only about 26-28 meters. Pollutants from the surface can get into the water of the wells, so there are conditions for formation of big quantities of nitrates at the water fields.

According to Table 2 the quantity of nitrate in water decreases from 51.2 $\mathrm{mg} / \mathrm{L}$ at the water field to $47.6 \mathrm{mg} / \mathrm{L}$ at the point of consumption when water is supplied using PE pipeline.

The water treatment plant at Zilenai settlement remove only total iron from water (from $128 \mu \mathrm{g} / \mathrm{L}$ to $52 \mu \mathrm{g} / \mathrm{L}$ ) though the quantity of nitrate increases (from $59.4 \mathrm{mg} / \mathrm{L}$ to $60.9 \mathrm{mg} / \mathrm{L}$ ) in the water pipeline, which is made of old cast iron pipes. As the quantities of nitrate at the water field and water pipeline exceed the permissible limits stated in Lithuanian Hygienic Norm HN 24:2003, at present 


\begin{tabular}{|c|c|c|c|c|}
\hline 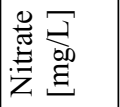 & i & $\begin{array}{l}8 \\
8 \\
0 \\
\dot{\gamma} \\
7\end{array}$ & 章 & $\begin{array}{l}8 \\
8 \\
\vdots \\
8 \\
0\end{array}$ \\
\hline 莺 & 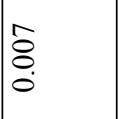 & $\begin{array}{l}0 \\
\delta \\
\dot{0} \\
v\end{array}$ & $\stackrel{\infty}{0}$ & 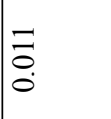 \\
\hline 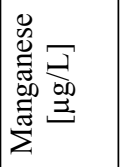 & $\begin{array}{l}0 \\
V\end{array}$ & $\begin{array}{l}0 \\
V\end{array}$ & 文 & ซ \\
\hline 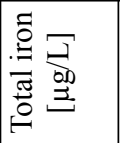 & 6 & $\begin{array}{l}0 \\
\vee\end{array}$ & $\stackrel{\infty}{\beth}$ & in \\
\hline 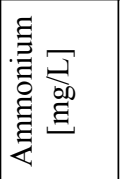 & 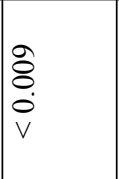 & $\stackrel{1}{0}$ & ڤె & $\frac{1}{0}$ \\
\hline 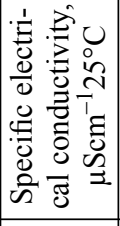 & $\underset{0}{0}$ & iे & $\underset{\infty}{\infty}$ & $\hat{\infty}$ \\
\hline$\frac{\pi}{2}$ & ma & ?ִ & 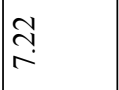 & $\underset{N}{N}$ \\
\hline 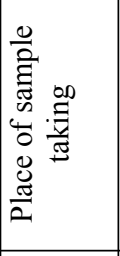 & 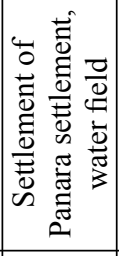 & 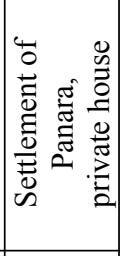 & 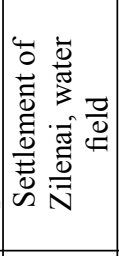 & 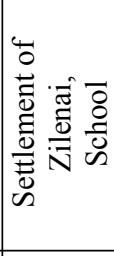 \\
\hline 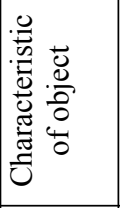 & 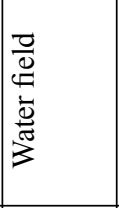 & 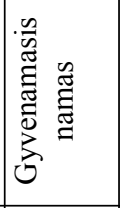 & 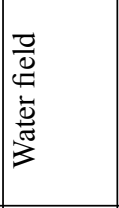 & 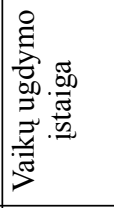 \\
\hline 䓌 & & ஓ & & ষ্ণ \\
\hline 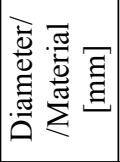 & & 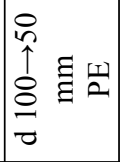 & & 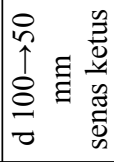 \\
\hline
\end{tabular}

the water is being taken from another well, the depth of which is 60 meters.

In water that is supplied from the wells to the water treatment plant the nitrification of ammonium (i.e. biochemical process) goes on. In this process the AOB participate. First, nitrite is formed and nitrate only then. The process goes on at the whole length of pipelines, i.e. from the wells to the consumer. Nitrifying bacteria participate in the process as well. Closer to the consumer the quantity of dissolved oxygen is getting higher and the more nitrite is oxidized into nitrate.

\section{CONCLUSIONS}

1. Treating underground water for drinking purposes at Zilenai settlement, non-removed nitrogen compounds influence the vital activity of micro organisms in the pipelines. Their remains consist of:

- Ammonium: from $0.025 \mathrm{mg} / \mathrm{L}$ to $0.012 \mathrm{mg} / \mathrm{L}$,

- Nitrite: from $0.018 \mathrm{mg} / \mathrm{L}$ to 0.012 $\mathrm{mg} / \mathrm{L}$,

- Nitrate: from 59.4 to $60.9 \mathrm{mg} / \mathrm{L}$.

2. When water consumption is low (at night) and water stays in wells, filters, water-towers, pipelines and other tanks for more than 12 hours the favourable conditions is created for the vital activity of micro organisms and the assimilation of nitrogen compounds, joining nitrogen into different forms of amines. The concentration of nitrate at the water tower, which is located in Varena water field, is $8.99 \mathrm{mg} / \mathrm{L}$. After the water is supplied through the old pipelines that are made of cast iron the concentration 
of nitrate increases up to $25.8 \mathrm{mg} / \mathrm{L}$ at Technology and Business School (at the farthest point in respect of the water tower).

3. In order to supply the water of permissible quality to the consumers that live at the farthest districts in respect of the water fields it is necessary to renew the whole old pipelines.

4. In order to avoid undesirable changes of water quality in the pipelines it is recommended to clean the pipelines and wash formed biofilm and sediments. According to the need the pipelines can be disinfected.

5. It is recommended to build water treatment plants for removal of nitrogen compounds at the water fields of Panara and Zilenai settlements.

\section{REFERENCES}

AGATEMOR C.P., OKOLO O. 2007: University of Benin water supply system: Microbiological and physico-chemical assessments. Environmentalist 27: 227 -239 .

LEE D., LEE J., KIM S. 2005: Diversity and dynamics of bacterial species in a biofilm at the end of the Seoul water distribution system. World Journal of Microbiology \& Biotechnology. 21: 155-162.

MARI T.T., LIPPONEN MERJA H., SUUTARI, PERTTI J. MARTIKAINEN. 2002: Occurrence of nitrifying bacteria and nitrification in Finnish drinking water distribution systems. Water Research 36, 4319-4329.

MARKKU J., LEHTOLA M.J., JUHNA T., MIETTINEN I.T., VARTIAINEN T., MARTIKAINEN P.J. 2004: Formation of biofilms in drinking water distribution networks, a case study in two cities in Finland and Latvia. J. Ind. Microbiol Biotechnol 31: 489-494.
MAZEIKIENE A., VALENTUKEVICIENE M., RIMEIKA M., MATUZEVICIUS A.B. DAUKNYS R. 2008: Removal of nitrates and ammonium ions from water using natural sorbent zeolite (clinoptilolite). Journal of Environmental Engineering and Landscape Management 16(1): 38-44.

NEVILLEA. 2001: Effect of cement paste on drinking water. Materials and Structures. Vol. 34: 367-372.

SRINIVASAN S., HARRINGTO G.W., XAGORARAKI I., RAMESH GOEL R. 2008: Factors affecting bulk to total bacteria ratio in drinking water distribution systems. Water Research 42, 3393-3404.

VALENTUKEVICIENE M., RIMEIKA M. 2007: Development of a Fluidized Batch Process Using Natural Powdered Zeolite (Clinoptilolite). Polish J. of Environ. Stud. Vol. 16, No 2, 283-288.

VALENTUKEVICIENE M. 2009: Applying backwash water in order to enhance removal of iron and ammonium from spent filters with fresh filter media. Environment Protection Engineering. Vol. 35, No 3, 135-144.

Streszczenie: Zmiany jakości wody w sieci wodociagowej na przyktadzie badań prowadzonych na Litwie. Celem badań było określenie zmian jakości wody wodociagowej następujących w wyniku jej transportu i dystrybucji. Badania przeprowadzono w systemie wodociagowym zasilanym ze studni głębinowych w mieście Varena na Litwie. $\mathrm{W}$ analizowanych próbach określano $\mathrm{pH}$, przewodnictwo, zawartość żelaza, manganu, amoniaku, azotanów i azotynów. Uzyskane wyniki wykazały, że woda z ujęcia głębinowego była bardzo podatna na rozwój bakterii w systemie jej dystrybucji. Obecność azotanów i azotynów w próbkach wody z wodociagu, była pozytywnie skorelowana z długością starych rur żelaznych i negatywnie skorelowana z długością nowo wybudowanej sieci. Uzyskane wyniki sugerują również, że wzrost stężeń azotynów w sieci wodociagowej byłby niższy, gdyby ich stężenie było poniżej poziomu wykrywalności na odpływie ze stacji uzdatniania. 
Można to osiagnąć przez zastosowanie uzdatniania biologicznego. Przedstawione wyniki należy traktować jako wstępne, a zjawisko wzrostu stężeń azotanów w wodzie transportowanej siecią wodociaggową wymaga dalszych obserwacji i bardziej szczegółowych badań.
MS. received November 2009
Authors' address:
Department of Water Management
Vilnius Gediminas Technical University
Sauletekio al. 11, APF, Vilnius-40,
LT-10223 Lithuania
e-mails: marina.valentukevicine@vgtu.lt 